DOI: 10.20472/IAC.2018.044.008

MEENA BHATIA

Birla Institute of Management Technology, India

MWILA MULENGA

Institute of Finance Management (IFM), Tanzania, United Republic of

\title{
DO ACCOUNTING NUMBERS HAVE ANY RELATION WITH STOCK PRICES? A CASE OF PUBLIC AND PRIVATE SECTOR BANKS OF INDIA
}

\begin{abstract}
:
Purpose: The purpose of this study is to examine the relationship between the accounting numbers and the share price of the banks in India, and also to study if there is any significance difference in the relevance of accounting numbers in case of public sector and private sector banks.

Design/methodology/approach-The study used panel least regression analysis by incorporating Fixed effect model (FEM) and Random effect model (REM), where nine set of accounting variables regressed against market share price of private and public sector banks for a period of 10 years from 2005 to 2014.

Findings -The empirical findings revealed that, out of nine independent variables used; the earnings per share, book value per share, assets turnover and current ratio were significant in private sector banks and earnings per share, book value per share, return on equity and net non-performing assets ratio were significant in public sector banks. Overall empirical findings reported that the accounting numbers in public sector banks is more relevant than that of private sector banks and this supports the hypothesis of the study that there is significant difference in the relevance of accounting numbers between public sector banks and private sector banks.

Practical implications -The empirical findings of this study contribute to existing literature and provide additional insight to Indian investors to understand the importance of accounting numbers in banking sector; also it provides insight to bankers by identifying accounting numbers which are accorded significance by the stock market.

Originality/value -To the best of author's knowledge, this is the first empirical study which compared the accounting numbers private and public sector banks of India.
\end{abstract}

\section{Keywords:}

Accounting information, Share price, Bombay stock exchange, Private sector banks, public sector banks, India 